\title{
El simbolismo de la celda y del atrio en los Padres del desierto como espacios de hospedaje de Cristo y del hermano
}

\author{
María Sara Cafferata • \\ Pontificia Universidad Católica Argentina \\ Centro de Investigaciones en Antopología Filosófica y Cultural \\ Buenos Aires - Argentina \\ mariasara3@gmail.com \\ Recibido 12.11.2020/Aprobado 22.02.2021 \\ DOI: https://doi.org/10.46553/teo.58.134.2021.p133-150
}

\section{RESUMEN}

Desde los albores de la espiritualidad cristiana, la celda fue un símbolo del espacio de soledad del alma a donde Cristo llega como huésped para ser recibido. El corazón del hombre es el destino del peregrinaje infinito que arriesgó el Verbo al encarnarse. Primera estación de un camino que, iniciando en el misterio trinitario, desciende hasta los abismos del hombre por el misterio de la encarnación para reemprender el ascenso hasta el Padre abrazando todo y a todos en el Cristo total que retorna a seno de la Trinidad. Fuera de la celda del encuentro con el divino huésped hay un atrio, como existía ya en las primeras ermitas, en los primeros cenobios. Celda, símbolo del corazón; atrio, símbolo del espacio de encuentro... es como el living de recepción, ya fuera del tálamo nupcial del amor místico, un paso más afuera, donde Cristo se acerca como peregrino en el hermano que llega. El simbolismo del atrio invita a abrirse para acoger a las puertas del corazón a cada hermano que llega a nosotros. El fuego del hogar que recibe en calidez es el Amor de Dios que arde e irradia desde el lugar eremítico del corazón. Los atrios frater-

\footnotetext{
- La autora es Doctora en Filosofía por la Universidad Nacional de Cuyo, diplomada en Bienes Culturales de la Iglesia por la Pontificia Universidad Gregoriana (Roma), y es profesora de Antropología, Ética y Metafísica en la Universidad Católica Argentina, y de Arte Cristiano en Escuela Superior de Economía y Administración de Empresas.
} 
nos de los diálogos de cielo como los de Benito y Escolástica o Agustín y Mónica o Teresita y sus hermanos se perfilan como sacramentos del Logos: signos sensibles del dialogo divino, participación y entrada en la Trinidad que es eterno Diálogo de Amor luminoso.

Palabras clave: Hospedaje; Simbolismo; Celda; Corazón; Patrística; Eremitas

The Symbolism of the Cell and the Atrium in the Desert Fathers as a Lodging for Christ and Fellow Man.

Abstract

Since the dawn of Christian spirituality the cell has been a symbol of the soul's place of solitude, where Christ arrives and is received as a guest. The human heart is the final destination of that infinite Pilgrimage which the Word undertook when it became incarnate. It is the first stopping-place on a path that, beginning from the mystery of the Trinity, descends into the depths of man through the mystery of the Incarnation and then climbs again to the Father who embraces everything and everyone in the complete Christ who returns to the bosom of the Trinity.

Outside the cell where the divine Guest is encountered there is an atrium, as was the case already in the first hermitages, the first monasteries. The cell, a symbol of the heart; the atrium, a symbol of the space of encounter - a receiving room, as it were, outside the nuptial chamber of mystic love, a step beyond it, where Christ approaches as a pilgrim in the brother who arrives. The symbolism of the atrium invites us to throw open the doors of the heart and embrace each brother as he reaches us. The hearth-fire that warms him as he comes in is the Love of God who burns and shines forth from within the hermitic space of the heart.

The fraternal atria of the heavenly dialogues, like those of Benedict and Scholastica, Augustine and Monica, or Thérèse of Lisieux and her brothers, come to be sacraments of the Logos: tangible signs of the divine dialogue, a way of entry and a participation in the Trinity, which is the eternal Dialogue of luminous Love.

Keywords: Lodging; Symbolism; Cell; Heart; Patristic; Hermit

\section{La celda}

\subsection{La celda o pozo interior}

«Permanece en tu celda, y tu celda te enseñará todo"

Abba Moises

Cristian de Chergé, el prior de los monjes cistercienses de Argelia asesinados en el año 1996, habla en su diario de un amigo musulmán con el que solía tener coloquios espirituales. Cuenta que un día fue su amigo a visitarlo y, deseoso de tener un tiempo de diálogo profundo con el monje, le dijo: «Hace tiempo que no 
bajamos a nuestros pozos...». ¡Bello símbolo el del pozo! Lleno de hondura, lleno de agua en su fondo. El pozo del alma remite a las profundidades propias del espíritu, ese espacio en lo más íntimo del corazón del hombre que los espirituales, los santos y los doctores de la Iglesia han expresado con distintas imágenes. Una de éstas es la de la celda, que tomaremos en particular para comenzar nuestra reflexión.

Muy temprano en la historia de la Iglesia encontramos ya este símbolo, proyectado desde la vida de aquellos hombres que, a partir de mediados del siglo III hasta el siglo $V,{ }^{2}$ tomaban distancia de la ciudad y se retiraban al desierto buscando en la soledad, el silencio, la oración y la penitencia, un camino de santidad. ${ }^{3}$ Sus enseñanzas, transmitidas primero oralmente, luego recopiladas por escrito por ellos mismos, encierran una profunda sabiduría, que expresa verdades profundas del cristianismo y del ser humano. ${ }^{4}$ En los Apotegmas de los Padres del desierto ${ }^{5}$ que expresaron esa sabiduría viva de aquellos primeros pasos de la vida en soledad con Dios, encontramos recurrentemente el concepto de celda. Frases como la

1 «A partir de un día en que me pidió, inesperadamente, que le enseñara a orar, M. tomó la costumbre de venir a conversar conmigo. Por eso, tenemos una larga historia de intercambio espiritual. Muchas veces he tenido que ser breve con él, cuando los huéspedes eran muchos y demandantes. Un día, encontró la forma para llamarme al orden: "iHace mucho tiempo que no hemos ahondado en nuestros pozos!" La imagen perduró. La utilizamos cuando sentimos la necesidad de un intercambio profundo.» Christian De Chergé, La esperanza invencible, (Buenos Aires: Lumen), 2007, 127.

2 Se toman estos primeros siglos en que el eremitismo fue el origen de la vida contemplativa en la Iglesia, pero hasta el día de hoy existe la vida eremítica como uno de los caminos de la vida cristiana, excepcional ciertamente, pero presente y vivo en sus distintas expresiones carismáticas.

3 Cf. Jean Claude Guy; I padri del deserto, (Milano: Ed. Paoline) 1997, 5.

4 «A quien busca ayuda en el camino espiritual, las palabras de los padres antiguos, celosamente custodiadas, ofrecen su sabiduría siempre actual, porque se dirigen a la profundidad del ser humano, al corazón del hombre, que lleva impresa la imagen de Dios Padre, que en cada tiempo y en cada lugar intenta despertar una vida a su imagen y semejanza». Sabino Chialà \& Lisa Cremaschi (a cura di), Detti editi e inediti dei Padri del deserto, (Matera: Qiqajon), 2002, 7.

5 Los Apophtegmata patrum, tradiciones que inicialmente se transmitían oralmente, ya en el siglo $V$ fueron recopiladas por los mismos eremitas, quienes ante el peligro que sufría la vida desértica egipciana -por las invasiones, las herejías, etc.- quisieron inmortalizar las enseñanzas de los Abba. Así se sucedieron las colecciones alfabéticas, sistemática, las traducciones y los agregados a las mismas a lo largo de los siglos, lo cual permitió que el tesoro de las enseñanzas de los ancianos Ilegara hasta nuestros días. Un estudio detallado sobre las diversas ediciones de los dichos se encuentra en Jean Claude Guy, S. J., Recherches sur la tradition grecque des Apophthegmata Patrum, (Bruxelles: Societé des Bollandistes), 1962. Cf. John Chryssavgis, Al cuore del deserto, (Matera: Ed. Qiqajon), 2004. 
siguiente se repiten una y otra vez: «Un hermano interrogó al Padre Ierace: "Dime una palabra: ¿cómo puedo salvarme?" Le respondió el anciano: "Permanece en tu celda; si tienes hambre, come, si tienes sed, bebe. No hables mal de nadie, y te salvarás" ». ${ }^{6}$

También leemos: «Un hermano se dirigió a donde vivía Abba Moisés para pedirle una palabra. El anciano le dijo: "Ve, permanece en tu celda, y tu celda te enseñará todo" $»$.?

El Padre Poimen, por su parte, enseña a los hermanos que le piden su palabra: «Un hermano preguntó al Padre Poimen: “¿Qué debo hacer?" El anciano dijo: "Si el Señor nos protege, ¿de qué nos preocuparemos?" "De nuestros pecados", dijo el hermano. Y el anciano dijo: "Entremos en nuestra celda, sentémonos, y pensemos en nuestros pecados; y el Señor en cada cosa vendrá a nosotros" ${ }^{\prime \prime}{ }^{8}$

En éstos y en muchos otros dichos la celda se presenta como un ideal. Permanecer en ella. No sucumbir a la tentación de dejarla. Ser fiel a la celda. Allí el monje realizaba todo, porque su vivienda era una pequeña casita con dos lugares, uno para dormir, y el otro, la celda, para realizar todo lo demás. Sobre todo, su actividad principal: la oración. ${ }^{9}$

El permanecer implica dos cosas esenciales: el estado físico de estar sentado, y la idea de mantenerse en ese estado. Sentado está quien se detiene, quien ha llegado al lugar de destino, quien no tiene apuro, quien está dispuesto a escuchar, quien está tranquilo, sin ansia. Y el mantenerse en ese estado remite a la palabra de Jesús en la última cena, cuando invitó a sus discípulos a permanecer en su amor. ${ }^{10}$ He aquí el espíritu que se esconde detrás del consejo de los Padres de permanecer en la celda para alcanzar la salvación. ${ }^{11}$

6 Luciana Mortari (a cura di), Vita e detti dei Padri del deserto, (Roma: Città Nuova), 2005, 262. Las traducciones del italiano al castellano son mías.

7 Sabino Chialà \& Lisa Cremaschi (a cura di), Detti editi e inediti.., 114.

8 Luciana Mortari (a cura di), Vita e detti..., 410.

9 Cf. Luis Glinka, ofm, Apotegmas de los Padres del Desierto, (Buenos Aires: Ed. Lumen), 1990, 11-21.

$10 \mathrm{Jn} 15,9 \mathrm{~b}$

11 Vemos multiplicarse las enseñanzas de los ancianos que, ante la pregunta del hermano sobre cómo salvarse o sobre cómo vivir, responden siempre lo mismo: permaneciendo en la 


\subsection{Dios, huésped del corazón}

«El que me ama será fiel a mi palabra, y mi Padre lo amará; iremos a él y habitaremos en él».

In 14,23

La celda de los Padres es el símbolo del lugar interior más profundo del alma. Este símbolo se prolonga en el tiempo y se profundiza en su sentido, como lo vemos en el siguiente párrafo de Guillermo de Saint Thierry en su Carta de Oro: «La celda es una tierra santa, un lugar santo donde el Señor y su servidor conversan a menudo como un hombre con su amigo, donde con frecuencia el alma fiel se une al Verbo de Dios, asociada como la esposa a su esposo; se hacen uno lo celeste y lo terrestre, lo divino y lo humano. Como el templo es el lugar santo de Dios, así la celda lo es del servidor de Dios»". ${ }^{12}$

El lugar interior simbolizado por la celda externa será también nombrado por otros santos y doctores, cada uno con su propio lenguaje. Así leemos en el Libro de las Moradas de Santa Teresa: «Cuando nuestro Señor es servido haber piedad de lo que padece y ha padecido por su deseo esta alma que ya espiritualmente ha tomado por esposa, primero que se consuma el matrimonio espiritual métela en su morada, que es esta séptima. Porque ansí como la tiene en el cielo, debe tener en el alma una estancia adonde sólo Su Majestad mora, y digamos otro cielo». ${ }^{13}$

Vemos en los textos recién citados que este lugar interior es como una hospedería que el alma tiene en su profundidad, en la cual ha de ser acogido el divino huésped. Ese Peregrino que llega a la morada interior del hombre es el mismo Dios, la mismísima

celda. Así lo aconseja el Padre Gelasio: «...permanece con paciencia en tu celda llorando tus pecados y no andes dando vueltas por ahí.» Luciana Mortari (a cura di), Vita e detti, p. 165; y asimismo el Padre Serapio: «Hijo, si quieres tener ganancia para tu vida espiritual, persevera en tu celda, porque el salir no te aporta tanta utilidad cuanto el permanecer en la celda.» Ibid, 479.

12 Guillermo de Saint Thierry, Carta de Oro, III, 1, 35 - (Azul: Ed. Monasterio Ntra. Sra. de los Ángeles), 2003, 31 .

13 Teresa de Jesús, Las Moradas del castillo interior, (Buenos Aires: Ed. Santa María), 2007, 166. 
Trinidad. Sigue así diciendo Santa Teresa: «Aquí se le comunican todas tres Personas, y la hablan, y la dan a entender aquellas palabras que dice el Evangelio que dijo el Señor: que vendrían El y el Padre y el Espíritu Santo a morar con el alma que le ama y guarda sus mandamientos». ${ }^{14}$

La idea explícita del huésped en referencia a Dios estaba ya presente siglos antes, como lo vemos en el siguiente párrafo de san Agustín: «Éste es el día que hizo el Señor; alegrémonos y gocémonos en él. Huid de las tinieblas. La embriaguez atañe a las tinieblas. No marchéis de aquí sobrios y regreséis ebrios; después de mediodía volveremos a vernos. El Espíritu Santo ha comenzado a habitar en vosotros. ¡Que no se tenga que marchar! No lo expulséis de vuestros corazones. Es buen huésped: si os encuentra vacíos, os llena; si hambrientos, os alimenta; finalmente, si os halla sedientos, os embriaga. Sea Él quien os embriague, pues dice el Apóstol: No os embriaguéis de vino, en el cual está todo desenfreno. $Y$, como queriendo enseñarnos con qué hemos de embriagarnos, añade: Antes bien, llenaos del Espíritu Santo, cantando entre vosotros con himnos, salmos y cánticos espirituales; cantando al Señor en vuestros corazones». ${ }^{15}$

Esta habitación del Espíritu en el alma es una presencia real y no solo metafórica. «El Nuevo Testamento habla con frecuencia del Espíritu Santo como enviado o dado a los discípulos de forma que inhabita en ellos ${ }^{16} .$. Los cristianos son templos del Espíritu Santo. En ellos habita Dios en forma análoga a como habitaba en el templo de Jerusalén ${ }^{17}$... Este nuevo modo de presencia ha de entenderse en toda su fuerza, como algo real, no como una metáfora o una hipérbole. Es una presencia sustancial, no meramente dinámica. No son sólo los

14 Ibid, p. 167.

15 San Agustín, Sermón 225, 4; también: Sermón 72ª 2: «Cuando el Espíritu habita en un hombre, lo llena, lo gobierna, lo impulsa, lo disuade del mal, lo estimula al bien, le hace suave la justicia, para que obre el bien por amor a la rectitud, no por temor al castigo. Por sí mismo el hombre no es capaz de ejecutar todo eso que he dicho. Pero, si tiene al Espíritu Santo como huésped, lo descubre también como su auxiliar en toda obra buena.».

16 cfr. Jn 15, 26; 16, 7; Gal 4, 6; Rom 5, 5; 1 Cor 3, 16-17; Rom 8, 11.

17 cfr. 1 Cor $3,16-17 ; 6,19 ; 2 \operatorname{Cor} 6,16$. 
dones del Espíritu los que llenan al hombre, sino que es el mismo Espíritu el que inhabita en nuestros corazones». ${ }^{18}$

También san Juan Clímaco alude al huésped del alma que en este caso es Cristo: «Pero Dios bueno, suave y manso, amigo dulce, consejero prudente, protector fuerte, jcuán inhumano, cuán temerario, es el que te arroja, el que aleja de su corazón a un huésped tan humilde y $\tan$ manso! ${ }^{19}$ El huésped dulce y manso es Cristo que dijo de sí: «Aprendan de mí, que soy manso y humilde de corazón». ${ }^{20}$

Resuenan también ante esta imagen las palabras del Apocalipsis: «Mira que estoy a la puerta y llamo, si me abres, entraré y cenaremos juntos». ${ }^{21}$ He aquí el divino huésped que toca a nuestra puerta y nos pide entrar, para alojarlo en nuestro corazón, para celebrar su Eucaristía dentro nuestro.

San Agustín se refiere a la presencia de Cristo cuando comenta el pasaje de Emaús en que los dos discípulos recibieron a Jesús resucitado como huésped en su Aldea:

«Por fin, amadísimos, hemos conocido el gran misterio. Escuchad. Caminaba con ellos, es acogido como huésped, fracciona el pan y le reconocen. No digamos nosotros que no conocemos a Cristo; lo conocemos si creemos. Ellos tenían a Cristo en la comida; nosotros lo tenemos dentro, en el alma. Mayor cosa es tener a Cristo en el corazón que tenerlo en casa. Nuestro corazón nos es más interior de lo que lo es nuestra casa». ${ }^{22}$

Con un lenguaje existencial, expresa esto mismo Zundel hablando simplemente de una Presencia: «Uno no puede ser alguien sino para Alguien y ese Alguien en el cual y por el cual nosotros llegamos a ser alguien, no puede ser, finalmente sino esta Presencia que nos espera en lo más íntimo de nosotros mismos». ${ }^{23}$

18 Lucas Francisco Mateo Secco, «Dulce huésped del alma», Scripta Theologica 30 (1998/2): 505-517.

19 San Juan Clímaco, La Santa Escala, (Buenos Aires: Ed. Lumen), 1998.

$20 \mathrm{Mt} 11,29$.

21 Ap. 3, 20.

22 San Agustín, Sermón 232, 7.

23 Maurice Zundel, «La vida espiritual, silencio de presencia», Cuadernos Monásticos Año XLI (2006), N $156(42-51), 45$. 
Esa presencia es La presencia, la más honda a la que el hombre puede llegar, y que funda esa relación Personal con Dios, que se nos da a través de Cristo, a semejanza de la relación entre Personas que se da en la Trinidad. ${ }^{24}$

Los textos que hasta ahora venimos analizando nos dan la idea de un espacio interior, simbólicamente hondísimo en las profundidades más recónditas de nuestro espíritu. Y a este punto podemos preguntarnos: ¿es sólo el alma, el espíritu humano, el que se impregna de la Presencia divina cuando Cristo viene como huésped?

Ante esta pregunta, quiero hacer presente algo del aporte luminoso del Siervo de Dios Luis María Etcheverry Boneo, cuyo pensamiento está aún escondido en los estudios del su proceso de Beatificación, pero cuyas potencialidades son enormes. El texto que propongo se refiere a la presencia de Cristo en el interior de la Virgen, por la Encarnación, que evoca de algún modo el tema que venimos tratando. Evidentemente el misterio de la presencia de Dios en el interior de María tiene una entidad esencialmente original, única, ya que en su seno Dios mismo se encarnó físicamente. Pero del ella se abre al mismo tiempo una potencialidad de comprensión teológica del misterio de la habitación de Dios, por Cristo, en nuestro espíritu, presencia que está llamada a impregnar no solo las dimensiones espirituales de nuestro ser, sino a comprender sacramentalmente también lo material y cada uno de los aspectos de lo humano.

Etcheverry Boneo distingue tres momentos en la vida de la Virgen: el que transcurre antes de la Anunciación, el que transcurre

24 Esa unión con Cristo que se realiza por su in-habitación en el alma es tan íntima que ha sido comparada por toda la historia de la mística cristiana con la unión esponsal: «Ese Alguien puede estar en nosotros sin que lo sepamos, mientras lo dejamos librado a un abandono absoluto, a una indiferencia tal que parece no existir... Es raro que llevemos la identificación hasta ese matrimonio de amor que haría de nuestra vida toda entera un compromiso nupcial. Un verdadero compromiso nupcial, si puede existir entre los esposos, es bien raro - confesémoslo- pero si puede existir, basta para llenar la vida, para colmarla maravillosamente, porque ese compromiso hace de cada gesto un gesto de amor, de cada trabajo una ofrenda de amor, de cada ausencia o presencia una renovación del amor y le da, en consecuencia, una dimensión infinita. Entonces todo, verdaderamente todo, se realiza con todos desde adentro y hasta la vajilla de la cocina deviene sacramental porque se inscribe en el rimo maravilloso del amor. Si la vida con Dios llegara a ser un matrimonio de amor, tendría el mismo carácter, sería toda entera una respiración de amor». Zundel, «La vida espiritual...», 48 . 
durante los nueve meses de gestación de Jesús, y el que sucede a su nacimiento. Hablando del segundo momento, justamente cuando María lo tiene en su seno físico, nos dice:

«...comienza enseguida el segundo período de la Virgen, el segundo gran momento de su existencia. La Virgen cuando lo recibe a Jesucristo en su interior lo trata tan bien, se pone tanto a disposición de Él, está tan abierta, en total sinceridad para oír todo lo que Jesús quiera decirle, para ver todo lo que Él quiera señalarle, está tan dócil, está tan rectamente dispuesta, está tan en las manos de Jesucristo que Él la maneja enteramente en su interior. Se produce una dialéctica, un intercambio maravilloso en esos nueve meses en los cuales la Virgen le va dando a Jesucristo célula tras célula y con ello Él se va tejiendo su vestido corporal y a la vez, dentro de la Virgen, va pintando su propia imagen y haciendo el alma de la Virgen cada vez más semejante a la de El mismo y por lo tanto a la divinidad». ${ }^{25}$

\section{Esta idea es profundizada con el símbolo del fuego que termi-} na de iluminar las implicancias de su significado:

«En la Encarnación todo el interior de la Virgen se vuelve cristiforme. Como cuando el fuego se acerca al hierro, el hierro se parece enseguida al fuego, y adquiere sus propiedades de iluminar, de encender, de calentar y la capacidad de irradiar y de transmitir todo eso... Cuando Dios se encarna en el seno físico de la Virgen, todo el seno psicológico, todo el corazón de la Virgen, todo su ser interior, se impregnan del Hijo de Dios. El mundo de valores, la cosmovisión interior de la Virgen, su modo de pensar, su imaginación, sus pensamientos, sus afectos, sus intuiciones, su estructura de pensar, de querer, de valorar, de sentir, de amar, de gozar, de padecer, de conmoverse, de actuar... todo eso se ve en la Virgen impregnado, dirigido, ordenado por el Hijo de Dios... en el momento mismo en el cual en sus entrañas recibe al mismo Dios que baja. Durante nueve meses en su interior, durante treinta y tantos años en el exterior, durante toda la vida, hasta que llegue el momento de la muerte, esa carne de la Virgen va a ser un instrumento en manos de su Hijo...». ${ }^{26}$

Vemos en el texto cómo el autor explicita esa presencia y esa impregnación de Cristo en María, recorriendo cada una de las dimensiones de su ser: espíritu y sensibilidad, e incluso su carne, como dice al final. Y si es cierto que en María la presencia de Cristo

25 Luis María Etcheverry Boneo, María, (Buenos Aires: Ed. Servidoras, 1985), 82.

26 Etcheverry Boneo, María, 57. 
fue un acontecimiento único ya que la Encarnación se realizó en ella, no es menos cierto que de un modo místico, el cristiano está llamado a recibir al Huésped divino hecho carne dentro suyo no solamente de un modo puramente espiritual: la prueba misma de esto es el Cuerpo de Cristo que comemos, materialmente, en la Eucaristía. La cena del Señor en la que su Cuerpo mismo se nos da como alimento es una muestra del deseo de Dios de hacerse uno con nosotros de un modo análogo, ciertamente, al que vivió María, pero sí real, tan real que San Pablo llegó a decir: «Vivo yo, mas no soy yo, sino que es Cristo quien vive en mí. ${ }^{27}$ Esa impregnación de María que se llenó del Verbo dentro de ella no solo en el espíritu sino en todo su ser, no puede sino irradiar como una luz en que su propio Hijo se irradia a través de ella, a través de su propio ser, de su propio cuerpo, de sus manos, de su sonrisa, de su mirada, de su cuerpo todo expresivo de su espíritu, como queda manifiesto en el pasaje de la visita a su prima:

\footnotetext{
«Y aconteció que estaba Ella tan aptamente constituida en signo sacramental de la cabeza a los pies en su espíritu, en su psicología, en su corazón, en su físico, que por decirlo así Jesucristo se salía de la vaina por usarla, por mostrarse y operar a través de Ella... Y todo se produjo: el descubrimiento de quién iba dentro de la Virgen y la donación de la gracia para el hijo y para la madre -Isabel-, todo se produjo al apenas darse el saludo inaugural de la Virgen, al apenas presentarse y saludar». ${ }^{28}$
}

Esa presencia interior en el espíritu del cristiano, en ese pozo interior del que nos hablaban los Padres ermitaños, es la hondura de un agua viva que Cristo ha traído del cielo para el hombre y que desde ese fondo quiere impregnar a todo el hombre: Él mismo quiere llenar nuestro ser, nuestros sentimientos, pensamientos, ideales, deseos, y también nuestra carne, nuestros gestos, nuestra mirada, nuestras palabras... todo nuestro ser corpóreo espiritual para hacerse presente hoy en el mundo. La Eucaristía es su propio Cuerpo que se hace uno con nosotros. Por ella entra el divino huésped en nues- 
tro cuerpo, en nuestro corazón, en nuestro espíritu: aunque verdaderamente podemos decir que no es Él quien entra en nosotros, sino nosotros que entramos en Él, en ese Cristo total que nos abarca.

\subsection{El hombre, huésped del Corazón de Cristo}

« Entra, alma mía, en el Costado herido de tu Señor crucificado! Penetra a través de la santa llaga hasta el Corazón lleno de amor de Jesús que por amor fue traspasado». Tomás de Kempis

La dinámica de la interiorización que venimos siguiendo hasta ahora va encontrando poco a poco un correlato que lo abraza y lo supera. Si el corazón del hombre es la hospedería de Cristo, profundizando hasta el final este misterio nos damos cuenta de que en realidad lo que supera y realiza todo esto es más profundo y más amplio: en realidad es el mismo Cristo quien nos aloja. Su Encarnación abrazó el misterio del hombre. Si con su venida al mundo el Verbo se hizo huésped del hombre, de la tierra, de su propia creación, lo hizo para abrazar Él mismo, en su propio Misterio, al hombre. A cada hombre y a todos los hombres y a toda la Creación para llevar todas las cosas a la morada del Padre.

Más profundo y verdadero que nuestro corazón como hospedería de Cristo es la verdad misteriosa de que el Corazón de Cristo es quien verdaderamente nos aloja. Somos nosotros sus huéspedes. Yo soy el huésped de su Corazón. Y un huésped que es recibido para quedarse. Él me abre su puerta para tenerme para siempre consigo, para llevarme para siempre a su casa Trinitaria. Este entrar en Cristo, en su misterio de Dios encarnado, ha sido visualizado por la espiritualidad y la mística cristiana con la doctrina de las llagas, que, en cuanto heridas abiertas físicas, figuran la entrada mística en el mismo ser de Cristo. « ¿Entra, alma mía, entra en el Costado derecho de tu Señor crucificado! Penetra a través de la santa herida hasta el Corazón lleno de Amor de Jesús que, por amor, fue atravesado por la lanza, y en las cavernas de la piedra (Ct 2, 14) descansa de la 
agitación del mundo. Acércate, oh hombre, a este Corazón silencioso, al Corazón de Dios que te abre su portal. Entra, bendecida de Dios, ¿qué haces afuera? Para ti se ha abierto la fuente de la vida, el camino de salvación, el arca del cielo y para ti se derraman innumerables perfumes. Quien se encuentra en la vertiente del río es capaz de calmar la sed del alma anhelante. Escucha, por tanto, también tú, a esta fuente del Salvador, la bebida del amor. Saca del costado de Jesús las dulces consolaciones de la Vida, a fin de que no vivas más en ti sino en Aquél que ha sido herido por ti. Ofrece tu corazón a aquel que te ha abierto el tuyo. $\gg^{29}$

En su artículo titulado Las llagas de lo imaginario Juan Quelas se refiere a las visiones de Juliana de Norwich, mística del siglo XV, quien vio en la herida de Cristo una imagen de la entrada espiritual en su misterio. Veamos algunos párrafos de la mística: "Con semblante bondadoso, nuestro buen Señor miró hacia su costado abierto y lo contempló con alegría; con su dulce mirada atrajo el entendimiento de su criatura hacia el interior por la misma herida; y allí le reveló un hermoso y deleitable lugar, lo bastante amplio como para toda la humanidad que será salvada y descansará en la paz y el amor. En esta dulce visión me mostró su bendito Corazón partido en dos, y en su alegría mostró a mi entendimiento una parte de su bendita divinidad, en la medida en que quiso, fortaleciendo a mi pobre alma para que pudiera comprender, por decirlo así, el amor eterno que no ha tenido principio y es y siempre será... Y así por su dulce gracia, por nuestra oración continua y humilde, entraremos en él en esta vida mediante los muchos toques secretos de suaves visiones y sentimientos espirituales, en la medida en que nuestra simplicidad sea capaz de recibirlos. Y esto es así y será por la gracia del Espíritu Santo, hasta el día en que muramos, todavía deseando ardientemente el amor. $\mathrm{Y}$ todos entraremos en nuestro

29 Tomás de Kempis, citado en Charles Andrè Bernard, II Cuore di Cristo e i suoi simboli, (Roma: Ed. AdP, 2008), 2008, 86. «... a fin de que no solo metiésemos en su costado nuestro dedo o nuestra mano, como Tomás, sino que a través de esa puerta abierta, entráramos todos hasta tu Corazón, oh Jesús» Guillermo de Saint Thierry, citado por Bernard, II Cuore di Cristo..., 77. 
Señor, conociéndonos a nosotros mismos con claridad y poseyendo plenamente a Dios; ocultos para siempre en Dios, viéndole verdaderamente, sintiéndole plenamente, escuchándole espiritualmente, oliéndole deliciosamente y saboreándole dulcemente. . ${ }^{30}$

A través del Corazón abierto de Cristo se abre el camino hacia el Padre. «La madre lleva al niño bajo su corazón, pero el Padre celeste nos lleva dentro del corazón. Es lo que nos ha revelado el Hijo. Él se ha dejado traspasar el Corazón por la lanza, a fin de que nosotros viésemos el amor ardiente del Padre para sus hijos.» ${ }^{31}$

\section{El atrio}

\subsection{La antesala de la celda}

«El diálogo místico con los otros es tanto más real cuanto mejor ha sido preparado en el silencio de una soledad donde Dios se respira».

Maurice Zundel

La celda de los Padres estaba antecedida por un atrio: un pequeño patiecito en el que el monje recibía a algún hermano que venía a pedir consejo, o a algún peregrino eventualmente. ${ }^{32}$

Si la celda es símbolo del espacio profundo interior, del pozo interior donde está Cristo, donde el alma vive en la soledad con Dios, a este atrio podemos considerarlo como la antesala de aquel otro espacio más profundo.

El hombre se mueve entre los dos polos de lo interior y lo exterior, de lo material y lo espiritual, se juega su ser en ambas dimensiones esenciales a su esencia. Vivir solamente en el afuera o hacia afuera,

30 Juan Quelas, «Las Ilagas de lo imaginario. Un encuentro entre Juliana de Norwich y Adolphe Gesché», Teología, Tomo XLVII, № 101, Abril (2010): 155-167.

31 Santa Catalina de Siena, citado por Bernard, II Cuore di Cristo..., 79.

32 «La celda de un anacoreta estaba circundada por un pequeño patiecito junto a un moro, cerrado por un portón o una puerta...En los restos arqueológico se encuentran todavía las piedras al lado del ingreso de una gruta, que corresponden a un pedazo de su lugar externo». Mortari, Vita e detti..., 164. 
externamente, como se da tanto hoy, es vivir en un vacío de lo humano. El llamado a la interioridad en tiempos como los nuestros se hace urgente para salvar al hombre en su esencia. El afuera del hombre, lo externo, su propio cuerpo y lo exterior a él, realidad que está también llamada a ser hospedada en su alma, empezarán a recibir la profundidad del espíritu solo si son vividos desde ese fondo más profundo, desde ese silencio del encuentro con uno mismo y con Dios.

Escuchemos las palabras de Maurice Zundel que iluminan esta dialéctica: «...en la medida en que uno ha descendido a la zona más profunda de sí mismo, donde no hay más ruido, y donde uno es capaz, a través de la acción, a través de esa especie de desdoblamiento que es la condición misma de una vida humana equilibrada, ya que no puede negar el aspecto visible del mundo, ni tampoco el aspecto interior, que están esencialmente ligados: en esa medida el interior se proyecta hacia el exterior, el uno conduce al otro y el otro se trasparenta en el primero, y uno llega necesariamente a la unificación de su existencia espontáneamente.» ${ }^{33}$

Viviendo el hospedar a Cristo y el permanecer con él en la celda interior, la mirada entonces ya puede volverse hacia afuera, debe volverse hacia afuera, ya puede y debe salir al atrio, para descubrir a Cristo que viene en el hermano.

\subsection{El hermano, huésped del corazón}

"El que los recibe a ustedes, me recibe a mi; y el que me recibe, recibe a Aquel que me envió» Mt 10,40

En la medida en que vivimos desde ese fondo, en la medida en que nuestra mirada surge desde esas fuentes de hondura amorosa, podemos aprender a descubrir también la venida de Cristo que toca a nuestra puerta desde el hermano. 
«Están los seres que tienen necesidad de nosotros, están todos los miserables, están todos esos vagabundos que, todos los días de la vida, vienen a golpearnos las puertas, está ese rostro de la miseria y de la desesperación que, al lastimar en nosotros un cierto sentido de la dignidad humana, nos vuelve fraternos con esa miseria, por lo menos nos inclina a sentirla como propia, nos convence de que, lo que podemos tener, pertenece por igual a los otros, de que ellos tienen el mismo derecho que nosotros a la seguridad... se trata sobre todo de un valor ilimitado en ellos, que uno recupera en la medida en que supera las apariencias y que comulga con lo más profundo de ellos mismos. Es siempre el mismo encuentro, no hay otros, se da siempre la misma Presencia fuera de la cual ninguna presencia es posible. ${ }^{34}$

¿Quiénes son esos seres que tienen necesidad, los vagabundos, los que tocan a nuestras puertas? Creo que lo es todo hombre. Somos todos vagabundos, errantes por el camino de esta vida y nos tocamos las puertas unos a otros.

Me quedo con estas últimas palabras de Zundel: «No hay otros, se da siempre la misma Presencia, fuera de la cual ninguna presencia es posible». ${ }^{35}$ La presencia de cada otro, de cada tú a nuestro yo más hondo, solo puede nacer verdaderamente de la Presencia divina vivida en la celda, entendida en el doble sentido de la celda del propio corazón y del Corazón de Cristo que nos aloja en Él -y a través de Él, en la morada Trinitaria-. El verdadero atrio de encuentro nace en la celda interior. El verdadero lugar de encuentro es el misterio Trinitario que nos abarca. Sólo podemos hospedar en el corazón al hermano si primero hemos acogido a Cristo que se hizo nuestro huésped y si nos hemos dejado alojar por El. Sólo entonces, Cristo puede hacerse huésped nuestro en cada hermano que toca a la puerta de nuestra vida, de nuestro espíritu, de nuestro yo. 
Y así la celda se alargará a todo y ese espacio íntimo inicial se hará un espacio infinito como el cielo, porque es el cielo mismo lo que llevamos adentro ya que llevamos a Cristo mismo que es el cielo.

De esa celda o ermita interior, de ese recinto sacro donde nuestro yo se une al Yo de Cristo y en Él al Padre en el Espíritu, unión mística que fue llamada nupcial, de esa celda misteriosa se proyecta la energía espiritual que nos hace abrazarlo todo o mejor, que nos hace vivir en el abrazo del Cristo total que todo lo envuelve. Dice Zundel: «Precisamente porque este encuentro con lo único necesario es un encuentro con todo el universo, es imposible alcanzar la verdadera soledad interior sin tener presente a toda la humanidad - y se la tiene tanto más presente cuanto más silencioso se está en la soledad inviolable de un compromiso nupcial-, justamente porque ese diálogo con el Señor, ese diálogo sin palabras, que es una presencia universal, entraña como consecuencia inevitable el retomar el diálogo con los demás y ese diálogo místico con los otros es tanto más real cuanto mejor ha sido preparado en el silencio de una soledad donde Dios se respira». ${ }^{36}$

\section{Huéspedes en la tierra, ciudadanos del cielo}

«La santa Trinidad es el hogar eterno.» Maurice Zundel

Todo hospedaje tiene su destino en Dios. Recibimos a Cristo en nuestro corazón, Recibimos a Cristo en cada hermano. Cristo mismo nos recibe como huéspedes a nosotros, en su Corazón, en su Misterio, en su Cuerpo, en su Eucaristía. En ella nos abraza y abraza todo. Con él y en comunidad eclesial caminamos peregrinos a la patria que nos alojará para siempre. La tierra es el espacio del hospedaje. El cielo es la morada eterna. ${ }^{37}$ 
Terminemos con las palabras de Agustín, que nos habla de esa morada que no tiene fin y a donde culminan todos nuestros viajes. «Seré huésped para siempre en tu tienda. Ya veis cómo el que clama es el mismo de quien hemos venido hablando. ¿Quién de nosotros es ese huésped por los siglos? Vivimos aquí pocos días, y nos vamos; somos huéspedes aquí; habitantes lo seremos en el cielo. Eres un huésped allí donde esperas oír la voz del Señor tu Dios, que te dice: emigra. Porque de aquella mansión eterna en el cielo, nadie te ordenará emigrar. Así que aquí eres huésped. Por eso se dice también en otro salmo: huésped y extranjero soy ante ti, como todos mis padres. Sí, somos aquí huéspedes; Dios nos dará allá unas mansiones eternas. En la casa de mi Padre, dice, hay muchas moradas. Dichas moradas no nos las dará como a huéspedes, sino como a ciudadanos que han de permanecer eternamente». ${ }^{38}$

\section{Bibliografía}

Bernard, Charles Andrè., Il Cuore di Cristo e $i$ suoi simboli, (Roma: Ed. AdP, 2008).

Chialà, Sabina \& Cremaschi, Lisa (a cura di), Detti editi e inediti dei Padri del deserto, (Matera: Qiqajon, 2002).

Clímaco, Juan, La Santa Escala, (Buenos Aires: Ed. Lumen, 1998).

Chryssavgis, John. , Al cuore del deserto, (Matera: Ed. Qiqajon, 2004).

De Chergé, Christian, La esperanza invencible, (Buenos Aires: Lumen, 2007).

Etcheverry Boneo, Luis María, María, (Buenos Aires: Ed. Servidoras, 1985).

Glinka, Luis, Apotegmas de los Padres del Desierto, (Buenos Aires: Ed. Lumen, 1990). 
Guy, Jean Claude, I padri del deserto, (Milano: Ed. Paoline, 1997).

Guy, Jean Claude, Recherches sur la tradition grecque des Apophthegmata Patrum, (Bruxelles: Societé des Bollandistes, 1962).

Mortari, Luciana (a cura di), Vita e detti dei Padri del deserto, (Roma: Città Nuova, 2005).

Quelas, Juan, «Las llagas de lo imaginario. Un encuentro entre Juliana de Norwich y Adolphe Gesché», en Revista Teología, Tomo XLVII, No 101, Abril (2010): 155-167.

Saint Thierry, Guillermo, Carta de Oro, (Azul: Ed. Monasterio Ntra. Sra. de los Ángeles, 2003).

San Agustín, Obras completas, (Madrid: BAC, 1985).

Secco, Lucas Francisco Mateo, "Dulce huésped del alma», en Scripta Theologica, $30(1998 / 2)$ 505-517.

Teresa de Jesús, Las Moradas del castillo interior, (Buenos Aires: Ed. Santa María, 2007).

Zundel, Maurice, «La vida espiritual, silencio de presencia», en Cuadernos Monásticos, Nº 156, Año XLI (2006), 42-51. 